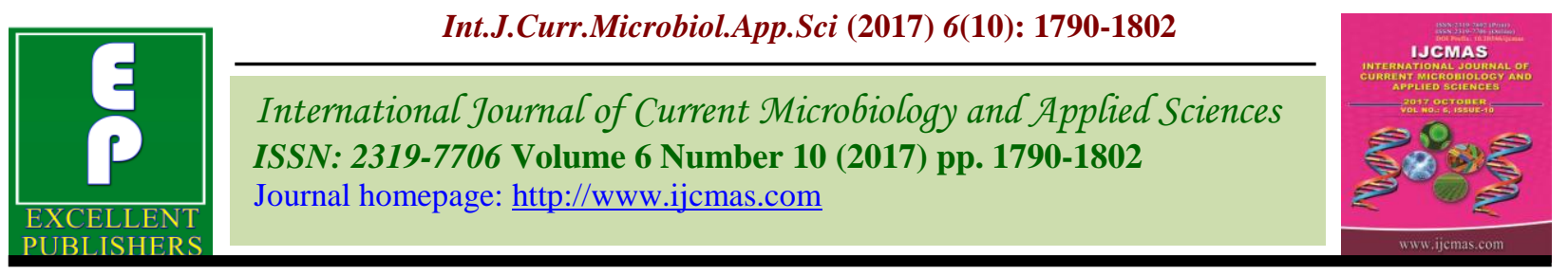

Original Research Article

https://doi.org/10.20546/ijcmas.2017.610.216

\title{
Reaction of Groundnut Advanced Breeding lines to Groundnut Bud Necrosis Disease
}

\author{
Afsha Tabassum ${ }^{1}$, Bharati N. Bhat ${ }^{1}$ and H. Sudini ${ }^{2 *}$ \\ ${ }^{1}$ Department of Plant Pathology, Professor Jayashankar Telangana State Agricultural University, \\ Hyderabad-500030, Telangana, India \\ ${ }^{2}$ Groundnut Pathology, ICRISAT, Patancheru, Hyderabad-502 324, Telangana, India \\ *Corresponding author
}

\section{A B S T R A C T}

Keywords

Groundnut bud necrosis disease, Groundnut bud necrosis virus, Hostplant resistance, Field screening.

Article Info

Accepted: 17 September 2017 Available Online: 10 October 2017
Forty advanced breeding lines were evaluated for reaction to Groundnut bud necrosis orthotospovirus (GBNV) in the field and greenhouse in Hyderabad, India during2013 rainy season. Results from natural infection showed eight resistant, 24 moderately resistant and eight moderately susceptible genotypes. There were no genotypes pertaining to highly resistant, susceptible and highly susceptible disease reaction grade. Greenhouse screening with mechanical sap inoculation showed all genotypes highly susceptible at 1:10 infected virus extract dilution, whereas at 1:100, two genotypes were moderately resistant, four moderately susceptible, ten susceptible and 24 highly susceptible. There were no genotypes pertaining to highly resistant and resistant disease reaction grade even at 1:100 infected virus extract dilution.

\section{Introduction}

Groundnut is one of the most important food legumes grown in subsistence and commercial farming throughout the tropical, sub-tropical and warm temperate regions of the world (Nwokolo, 1996), with an annual world production of 41.19 Mt from 24.71 Mha (FAOSTAT, 2014). Predominantly rainfed cultivation in marginal landsof many Asian and sub-Saharan African countries, poor seed systems, and the occurrence of many economically important insect pests, fungal diseases, and viral diseases at different stages of crop growth are primary factors responsible for low yields in groundnut (Reddy et al., 1992).
GBNV belongs to family Tospoviridae and responsible for causing Groundnut Bud Necrosis Disease (GBND) in groundnut (Reddy, 1991). GBNV is an economically important Tospovirus and its distribution is confined to South and Southeast Asian countries namely China, India, Nepal, Pakistan, Sri Lanka and Thailand (Dwivedi et al., 1995). The name Tospovirus (renamed Orthotospovirus) (Adams et al., 2017, Briese et al., 2016) was given after the discovery of Tomato spotted wilt virus (TSWV) in Australia in 1915.The disease was first recorded in India at Indian Agricultural Research Institute in 1949 (Reddy et al., 
1995). GBND in India until 1990 was reported to be caused by TSWV. Serological comparisons and sequencing of nucleic acids revealed the existence of several distinct Tospoviruses and GBNV was found to be serologically distinct from other Tospoviruses such as TSWV and Impatiens necrotic spot orthotospovirus (INSV) (Reddy et al., 1995). This virus is mechanically transmissible, but in nature, it is transmitted by the vector Thrips palmi in persistent manner (Vijayalakshmi, 1995).

Symptoms initially appear on young quadrifoliates as mild chlorotic mottle or spots, which develop into necrotic or chlorotic rings and streaks. This is followed by death of terminal bud. Secondary symptoms are stunting, auxiliary shoot proliferation, and malformation of leaflets (Reddy et al., 1995). However, the symptomatology varies depending on the strain, host species and genotype, and is also influenced by environmental factors such as temperature.

Thrips-transmitted Tospoviruses cause significant losses in yield and quality of produce from vegetable, legume and ornamental crops in many parts of the world (Mumford et al., 1996; Pappu, 1997; Pearce, 2005; Persley et al., 2006). GBND became economically important during the late 1960's when incidences up to $100 \%$ were recorded in many groundnut growing regions of the country. Incidence of GBND ranging from 5 to $80 \%$, and yield losses of up to $50 \%$, worth more than \$89 million in India alone, have been reported (APS, 2013). Substantial decrease in plant stand occurs, during infection at early stages of crop growth leading to considerable yield losses, but infection at later stages may still cause significant losses in the yield and quality of produce (Culbreath et al., 2003).

In India, $80 \%$ of groundnut sowing is taken up in kharif season (June-September) and sometimes with late onset of monsoon, JulyAugust sowings are usually in practice. Maximum thrips populations were observed from $2^{\text {nd }}$ week of July to end of August resulting in complete crop loss (Vijayalakshmi, 1995). There is no practically feasible control measure currently available for GBNV in groundnut. However, by using certain cultural practices such as adjustment of planting date coinciding with low levels of thrips activity, intercropping with fast growing cereals (Reddy et al., 2000) and close planting (Basu, 1995; Buiel and Parlevliet, 1996; Wongkaew, 1995), the disease incidence can be reduced. Control of this virus disease through crop rotation and removal of alternate weed hosts have met with limited success (Rao et al., 2013). Efforts to control vector with insecticides have been mostly unsuccessful. Indiscriminate use of insecticides is leading to the development of resistance in vector. In this context, genetic resistance remains the most economical method for the resource poor farmers. So far, the released varieties are found to be susceptible to GBND. Identification of GBND resistant sources in newly developed advanced breeding lines which are agronomically superior would help in recommending and release of these genotypes for GBND endemic locations. Keeping in view the economic importance of the disease in most of the groundnut growing areas and lack of available resistance sources to GBND, present work has been taken up.

\section{Materials and Methods}

\section{Field screening}

During kharif 2013, 40 advanced breeding lines along with a resistant check ICGV 86031 and known susceptible check JL 24 were sown in a replicated field trial using a Alpha Lattice Design on the ICRISAT farm at Patancheru, India. Seeds were pre-treated with Thiram (dimethyldithiocarbamate) to 
prevent from any seedborne and soilborne fungal infections. Field lay-out consists of three rows of $4 \mathrm{~m}$ length with a row to row spacing of $60 \mathrm{~cm}$ and plant to plant spacing of $25 \mathrm{~cm}$ within the rows for each line. GBNV susceptible check, JL 24 was planted all around the field to create epiphytotic conditions. Recommended package of practices was followed to raise the crop and to promote a natural infection of GBNV. The crop was not sprayed with any insecticide to encourage thrips movement and infestation. The reaction of entries under field conditions was assessed by recording the disease incidence and disease severity at fortnightly intervals, starting from 30 days after sowing (DAS) to 90 DAS. The test genotypes were grouped into six distinct groups using 0-5 scale (Sunkad et al., 2000) based on disease incidence. These include highly resistant (0 to $1.0 \%$ ); resistant (1.1 to $5.0 \%$ ); moderately resistant (5.1to 10.0\%); moderately susceptible (10.1to 25.0\%); susceptible (25.1to $50.0 \%$ ); highly susceptible (50.1 and above). Disease severity (DS) score of 1-5 were also given by randomly tagging five plants per treatment with $1=$ no symptom, $2=$ no systemic symptom but with spots on some leaves, $3=$ systemic symptoms with top chlorosis but no stunting, $4=$ systemic symptoms with strong distortion and stunting, and 5 = plants showing severe necrosis and stunting (Pensuk et al., 2002).

\section{Greenhouse screening}

GBNV (ICRISAT isolate) maintained on groundnut plants was used for preparation of the inoculum. In kharif 2013, the same 40 genotypes were also evaluated for GBNV resistance by mechanical inoculation (using a $10^{-1}$ and $10^{-2}$ dilution of infected plant extract) under controlled greenhouse conditions. The plants were raised in plastic pots ( $5 "$ diameter) @ 3 plants pot $^{-1}$. Each genotype was grown in three replications, six plants (two pots) per replication. Virus inoculum was freshly prepared from the infected leaves of groundnut ground in a chilled mortar and pestle using phosphate buffer $(0.05 \mathrm{M}, \mathrm{pH} 7.0)$ @ 1:10 (w/v) and 1:100 (w/v). The virus inoculum was rubbed onto all of the opened leaves of 8 to 10 day old test seedlings and rinsed with deionised water. All the pots were maintained at $25^{\circ}$ Cand $75 \% \mathrm{RH}$ in a controlled greenhouse for uniform infection. The observations that were recorded included disease incidence and disease severity as described earlier.

\section{Enzyme Linked Immunosorbent Assay (ELISA)}

Direct antigen coating (DAC) ELISA was carried out to detect the presence of GBNV in all the test genotypes that were challenged with the virus in greenhouse experiments, and for the confirmation of natural infection of plants in field experiment studies as suggested previously (Hobbs et al., 1987).

Greenhouse maintained GBNV (ICRISAT isolate) on groundnut served as known positive control and healthy leaves of groundnut as healthy control. All leaf samples were ground using carbonate buffer, $0.01 \mathrm{M}$, $\mathrm{pH} 9.6$ with sodium diethyl dithiocarbamate (DIECA) as antioxidant. Polyclonal antiserum of GBNV with 1:20,000 dilution was used. ALP-labelled anti rabbit IgG was added at a dilution of 1:5000 and absorbance values at $405 \mathrm{~nm}$ were measured using 'Bio RAD iMark' ELISA reader after $30 \mathrm{~min}$. of reaction. The readings were considered positive if they were five times more than the healthy samples (-ve control).

\section{Statistical analysis}

ANOVA was performed using PROC MIX SAS 9.3 software (SAS Institute Inc., Cary, $\mathrm{NC}$, USA) to determine the difference in disease incidence and severity data collected in field experiment. 


\section{Results and Discussion}

\section{Screening for field resistance to GBND}

\section{Disease incidence}

The average GBND incidence in the tested genotypes ranged from 2.57 to $22.71 \%$ compared to $4.04 \%$ in ICGV 86031 (resistant check) and $25.45 \%$ in JL 24 (susceptible check) (Table 1). With regard to per cent GBND incidence in the field, four genotypes viz., ICGV 07220 (2.57 \%), ICGV 00350 (2.64\%), ICGV 00351(3.36\%), ICGV 00211 $(4.02 \%)$ were found to be resistant and significantly superior to the resistant check ICGV 86031 (4.04\%). Out of the 40 genotypes tested, eight genotypes viz., ICGV 00201, 00211, 86699, 03042, 07220, 06146, 00350 and ICGV 00351 were resistant (disease incidence of 2.57 to $4.99 \%$ ). Twenty four genotypes viz., ICGV 00187, 00189, 00191, 00202, 00203, 00206, 00213, 00241, 00246, 00247, 03057, 06100, 07222, 05155, 02266, 87846, 00348, 93260, 93261, 89280, 92195, 92035, ICGS 76 and ICR 48 were moderately resistant (5.13 to $9.93 \%)$. Eight genotypes viz., ICGV 99058, 99072, 00162, 86590, 91114, 00308, 93468 and ICGS 44, were moderately susceptible (10.21 to 22.71 $\%)$. There were no genotypes pertaining to highly resistant, susceptible and highly susceptible disease reaction grade.

\section{Disease severity}

The average GBND disease severity in these genotypes ranged from 1.99 to 4.32 compared to 2.33 in ICGV 86031 (resistant check) and 4.67 in JL 24 (susceptible check). The genotypes ICGV 00187 (2.00), ICGV 00191 (2.00), ICGV 00201 (1.99), ICGV 00202 (2.00), ICGV 00206 (2.00), ICGV 00211 (2.00), ICGV 00213 (2.00), ICGV 00247 (1.99), ICGV 86699 (2.01), ICGV 07222 (2.01), ICGV 07220 (2.00), ICGV 06146
(1.99) and ICGV 87846 (2.00) showed less disease severity compared to resistant check ICGV 86031 (2.33). Of all the genotypes tested, none of them showed high disease severity compared to susceptible check JL 24 (4.67) indicating the superiority of JL 24 as susceptible check. The disease severity was in the range of 1.99 - 3.02 in resistant genotypes, $1.99-4.01$ in moderately resistant genotypes and $2.66-4.32$ in moderately susceptible genotypes.

\section{DAC-ELISA}

Leaf samples of few genotypes showing resistant, moderately resistant and moderately susceptible disease reaction were randomly collected, along with resistant (ICGV 86031) and susceptible (JL 24) check and the samples were subjected to ELISA test for further confirmation of field reaction. The resistant genotypes viz., ICGV 03042, 00350 and ICGV 00351 gave negative reaction to GBNV antiserum and the absorbance values at 405 $\mathrm{nm}$ was in the range of $0.157-0.354$ confirming their resistant reaction grade. The moderately resistant genotypes viz., ICGV 00187, 00189, 00213, 00241, 05155, 02266, 93261, 89280, 92195, 92035 and ICR 48 gave 16.66 to $66.66 \%$ infection with GBNV antiserum and the absorbance values at 405 $\mathrm{nm}$ was in the range of $0.137-2.910$ confirming their moderately resistant reaction.

The moderately susceptible genotypes viz., ICGV 99058, 99072, 00162, 86590, 91114, 00308, 93468 and ICGS 44 gave $100 \%$ infection with GBNV antiserum and the absorbance values was in the range of 1.669 3.427 confirming their moderately susceptible reaction. The genotypes ICGV 86031 (resistant check) and JL 24 (susceptible check) gave zero and $100 \%$ infection respectively with GBNV antiserum which was in conformity with their disease reaction under field conditions. 


\section{Screening for resistance to vector and virus}

\section{Disease incidence}

The average disease incidence at 1:10 virus concentration ranged from 64.71 to $100 \%$ compared to $72.22 \%$ in ICGV 86031 (resistant check) and $94.44 \%$ in JL 24 (susceptible check) at 21 DAI (Table 2).

The average disease incidence at 1:100 virus concentration ranged from 5.56 to $100 \%$ compared to 26.67 in ICGV 86031 (resistant check) and $77.78 \%$ in JL 24 (susceptible check) (Table 3).

The data revealed that out of the 40 genotypes tested at 1:100 dilution, two genotypes viz., ICGV 00213, 06146were moderately resistant (disease incidence of 5.56 and $7.14 \%$ ), four genotypes viz., ICGV 03057,07222, 07220 and ICGS 76 were moderately susceptible $(11.11-25 \%)$, ten genotypes viz., ICGV 00187, 00191, 00202, 00203, 03042, 06100, 05155, 93260, ICGS 44 and ICR 48 were susceptible $(26.67-50 \%)$ and twenty four genotype viz., ICGV 99058, 99072, 00162, 00189, 00201, 00206, 00211, 00241, 00246, 00247, 86590, 86699,91114, 00308, 02266, 87846, 93468, 00348, 00350, 00351, 93261, 89280, 92195 and ICGV 92035 were highly susceptible $(52.94-100 \%)$.

There were no genotypes pertaining to highly resistant and resistant disease reaction grade.

\section{Disease severity}

The average GBND disease severity in these genotypes at 1:10 virus concentration ranged from 2 to 5 compared to 4 in ICGV 86031 (resistant check) and 5 in JL 24 (susceptible check). At 1:100 virus concentration disease severity ranged from 2 to 4 compared to 2 in ICGV 86031 (resistant check) and 4 in JL 24 (susceptible check).

\section{DAC-ELISA}

The genotypes showing moderately resistant, moderately susceptible and susceptible reaction at 1:100 dilution of virus concentration were selected for ELISA test. ICGV 86031 (resistant check) and JL 24 (susceptible check) at 1:10 and 1:100 dilution of virus concentration were also tested by ELISA. The moderately resistant genotypes viz., ICGV 00213 and ICGV 06146 gave positive reaction with 6.11 and $28.57 \%$ infection with GBNV antiserum and the absorbance values at $405 \mathrm{~nm}$ was in the range of $0.090-1.624$ confirming their moderately resistant reaction grade. The moderately susceptible genotypes viz., ICGV 03057, 07222, 07220 and ICGS 76 gave positive reaction with 12.5 - $50 \%$ infection with GBNV antiserum and the absorbance values at $405 \mathrm{~nm}$ was in the range of $0.100-1.841$ confirming their moderately susceptible reaction grade. The susceptible genotypes viz., ICGV 00187, 00191, 00202, 00203, 03042, 06100, 05155, 93260, ICGS 44 and ICR 48 gave positive reaction with 73.33 $93.75 \%$ incidence to GBNV antiserum and the absorbance values at $405 \mathrm{~nm}$ was in the range of $0.094-1.941$ confirming their susceptible reaction grade. The resistant check ICGV 86031 at 1:10 virus concentration and 1:100 virus concentration gave positive reaction with 93.33 and $38.09 \%$ infection to GBNV antiserum and the absorbance values at $405 \mathrm{~nm}$ was in the range of $0.407-2.559$ and $0.088-1.820$ respectively. The susceptible check JL 24 at 1:10 virus concentration and 1:100 virus concentration gave positive reaction with 100 and $85.71 \%$ infection to GBNV antiserum and the absorbance values at $405 \mathrm{~nm}$ was in the range of $0.593-2.218$ and $0.397-2.129$ respectively.

The typical symptoms of GBNV such as chlorotic or necrotic spots on leaves, thrips 
injury on leaves, severe chlorosis of top leaves, bushy and stunted growth, severe necrosis and death of bud subsequently death of plants along with vector T. palmi was observed during 30 - 60 DAS. Significant differences in disease incidence were observed at different stages of the crop. Although, there were significant differences in disease incidence among genotypes at 30 DAS, some of the resistant lines could not be differentiated from susceptible lines. The mean disease incidence was low at 30 DAS and reached peak levels at 60 DAS when the crop was at flowering. The young plants are more succulent and attract the thrips for feeding. Thereafter, constant or gradual increase in disease incidence was observed at senescence stage. In natural conditions, the decrease in susceptibility of the plant with the age of the crop may be due to increase in resistance of plants to the virus infection. Significant differences in $T$. palmi populations at different stages of green gram crop were reported (Sreekanth et al., 2002).

Low population (15.6) was observed at 15 DAS and thereafter increased progressively up to 45 DAS to reach higher levels (72.1). At 60 DAS, population dwindled to lower levels (17.1) almost similar to the levels at 15 DAS. Since assessment at 45 and 60 DAS for disease incidence clearly differentiated groundnut genotypes for resistance to GBND, the appropriate time for assessment could be considered by the magnitude of genotypic variations in disease incidence.

Significant difference in disease incidence was found between genotypes ICGV 91114 and ICGV 99058, 99072, 00162, 86590, 00308, 93468, ICGS 44. This might be due to difference in genetic makeup and leaf characters such as hairiness, glossy, smooth etc. that resist the vector feeding on them and subsequent block in movement of virus once it enters the plant. The genotypes with thick leaves, glossiness and hairiness showed less disease incidence compared to genotypes having thin, smooth and non-glossy leaves.

In our study, late sowing of the genotypes fairly coincided with the reasonably high vector populations. Yet, our findings indicate that low disease incidence in these genotypes is due to their superiority in curtailing the thrips feeding and subsequently disease incidence. Field resistant varieties reported here are not immune to the disease but have reduced disease incidence under field conditions. Resistance in these genotypes might be due to non-preference by the thrips vector and/or resistance to GBNV infection or multiplication and spread. Similar findings were opinedby (Amin 1985) that resistance in case of groundnut cv Robut 33-1 is due to resistance to the vector, perhaps combined with resistance or tolerance to GBNV.

Resistant genotypes reduced the rate of epidemic development with considerable reduction in the incidence of GBNV (Culbreath et al., 1993; Buiel and Parlevliet, 1996). So, the genotypes showing high resistance or resistance response could be used as seed material after screening of genotypes further in different trials.

All the genotypes were highly susceptible to GBNV at higher virus concentration (1:10 dilution of the infected tissue). Previous reports were also indicated the same (Rao et al., 2006, Dwivedi et al., 1995). The genotypes ICGV 00213, 03057, 07220, 06146, ICGS 76 and ICR 48 showed no disease incidence at 7 DAI for both 1:10 and $1: 100$ virus concentrations indicating their longer incubation period. At 1:10 virus concentration, due to high disease pressure these genotypes showed highly susceptible disease reaction at 21 DAI. At 1:100 virus concentrations, these genotypes showed moderately resistant and moderately susceptible disease reaction except ICR 48 which showed susceptible disease reaction. 
Table.1 Disease incidence of groundnut advanced breeding lines for their natural reaction to GBNV infection under field conditions during kharif 2013, at ICRISAT, Patancheru

\begin{tabular}{|c|c|c|c|c|c|c|}
\hline \multirow[t]{2}{*}{ S. No. } & \multirow[t]{2}{*}{ Genotype } & \multicolumn{5}{|c|}{ Per cent Disease Incidence* at } \\
\hline & & 30DAS & 45DAS & 60DAS & 75DAS & 90DAS \\
\hline 1 & ICGV 99058 & $4.22(\mathrm{R})$ & 9.32(MR) & 11.49(MS) & 11.49(MS) & 11.49(MS) \\
\hline 2 & ICGV 99072 & $3.95(\mathrm{R})$ & $5.59(\mathrm{MR})$ & 10.65(MS) & 10.65(MS) & 10.65(MS) \\
\hline 3 & ICGV 00162 & $4.22(\mathrm{R})$ & 6.93(MR) & 9.01(MR) & $10.75(\mathrm{MS})$ & 11.44(MS) \\
\hline 4 & ICGV 00187 & $0.86(\mathrm{HR})$ & $4.36(\mathrm{R})$ & 6.99(MR) & 6.99(MR) & 6.99(MR) \\
\hline 5 & ICGV 00189 & $2.42(\mathrm{R})$ & $2.42(\mathrm{R})$ & 6.36(MR) & 7.84(MR) & $8.58(\mathrm{MR})$ \\
\hline 6 & ICGV 00191 & $0.66(\mathrm{HR})$ & $4.30(\mathrm{R})$ & 5.89(MR) & 6.72(MR) & 6.72(MR) \\
\hline 7 & ICGV 00201 & $1.45(\mathrm{R})$ & $3.57(\mathrm{R})$ & 4.99(R) & 4.99(R) & 4.99(R) \\
\hline 8 & ICGV 00202 & $1.60(\mathrm{R})$ & 5.22(MR) & 5.91(MR) & 5.91(MR) & 6.61(MR) \\
\hline 9 & ICGV 00203 & $0.84(\mathrm{HR})$ & $3.42(\mathrm{R})$ & $5.13(\mathrm{MR})$ & $5.13(\mathrm{MR})$ & $5.13(\mathrm{MR})$ \\
\hline 10 & ICGV 00206 & $0.03(\mathrm{HR})$ & $2.60(\mathrm{R})$ & $3.65(\mathrm{R})$ & $5.52(\mathrm{MR})$ & $6.56(\mathrm{MR})$ \\
\hline 11 & ICGV 00211 & $0.81(\mathrm{HR})$ & $1.58(\mathrm{R})$ & $4.02(\mathrm{R})$ & $4.02(\mathrm{R})$ & $4.02(\mathrm{R})$ \\
\hline 12 & ICGV 00213 & $1.47(\mathrm{R})$ & $4.38(\mathrm{R})$ & 5.93(MR) & $5.93(\mathrm{MR})$ & $5.93(\mathrm{MR})$ \\
\hline 13 & ICGV 00241 & $1.79(\mathrm{R})$ & $4.21(\mathrm{R})$ & 6.34(MR) & 7.35(MR) & 7.35(MR) \\
\hline 14 & ICGV 00246 & 4.04(R) & $6.17(\mathrm{MR})$ & 7.07(MR) & 7.07(MR) & 7.07(MR) \\
\hline 15 & ICGV 00247 & $2.40(\mathrm{R})$ & 5.53(MR) & 7.07(MR) & 7.07(MR) & 7.07(MR) \\
\hline 16 & ICGV 86590 & $6.38(\mathrm{MR})$ & $9.58(\mathrm{MR})$ & $9.58(\mathrm{MR})$ & $10.23(\mathrm{MS})$ & $10.23(\mathrm{MS})$ \\
\hline 17 & ICGV 86699 & $0.63(\mathrm{HR})$ & $2.48(\mathrm{R})$ & $3.10(\mathrm{R})$ & $4.33(\mathrm{R})$ & $4.33(\mathrm{R})$ \\
\hline 18 & ICGV 91114 & 7.98(MR) & 19.09(MS) & 22.71(MS) & 22.71(MS) & 22.71(MS) \\
\hline 19 & ICGV 00308 & $3.82(\mathrm{R})$ & $10.72(\mathrm{MS})$ & $10.72(\mathrm{MS})$ & $10.72(\mathrm{MS})$ & 10.72(MS) \\
\hline 20 & ICGV 03042 & $2.08(\mathrm{R})$ & $4.20(\mathrm{R})$ & $4.20(\mathrm{R})$ & $4.92(\mathrm{R})$ & $4.92(\mathrm{R})$ \\
\hline 21 & ICGV 03057 & $3.34(\mathrm{R})$ & $5.03(\mathrm{MR})$ & 5.71(MR) & 5.71(MR) & 5.71(MR) \\
\hline 22 & ICGV 06100 & $2.59(\mathrm{R})$ & $4.14(\mathrm{R})$ & 4.92(R) & 5.79(MR) & 6.67(MR) \\
\hline 23 & ICGV 07222 & $0.71(\mathrm{HR})$ & $3.07(\mathrm{R})$ & $6.04(\mathrm{MR})$ & $6.04(\mathrm{MR})$ & $6.04(\mathrm{MR})$ \\
\hline 24 & ICGV 07220 & $0.63(\mathrm{HR})$ & $1.25(\mathrm{R})$ & $1.89(\mathrm{R})$ & $2.57(\mathrm{R})$ & $2.57(\mathrm{R})$ \\
\hline 25 & ICGV 05155 & $2.09(\mathrm{R})$ & $4.40(\mathrm{R})$ & 5.04(MR) & 5.87(MR) & 6.71(MR) \\
\hline 26 & ICGV 06146 & $1.40(\mathrm{R})$ & $2.18(\mathrm{R})$ & $3.63(\mathrm{R})$ & $4.31(\mathrm{R})$ & $4.31(\mathrm{R})$ \\
\hline 27 & ICGV 02266 & $3.80(\mathrm{R})$ & $6.94(\mathrm{MR})$ & 6.94(MR) & 7.57(MR) & $8.20(\mathrm{MR})$ \\
\hline 28 & ICGV 87846 & $1.22(\mathrm{R})$ & $4.34(\mathrm{R})$ & $6.21(\mathrm{MR})$ & $6.21(\mathrm{MR})$ & $6.21(\mathrm{MR})$ \\
\hline 29 & ICGV 93468 & $4.09(\mathrm{R})$ & $11.75(\mathrm{MS})$ & 13.08(MS) & 13.08(MS) & 13.08(MS) \\
\hline 30 & ICGV 00348 & $2.17(\mathrm{R})$ & $2.92(\mathrm{R})$ & $5.90(\mathrm{MR})$ & $7.45(\mathrm{MR})$ & $7.45(\mathrm{MR})$ \\
\hline 31 & ICGV 00350 & $2.02(\mathrm{R})$ & $2.64(\mathrm{R})$ & $2.64(\mathrm{R})$ & $2.64(\mathrm{R})$ & $2.64(\mathrm{R})$ \\
\hline 32 & ICGV 00351 & 2.74(R) & $2.74(\mathrm{R})$ & $3.36(\mathrm{R})$ & $3.36(\mathrm{R})$ & $3.36(\mathrm{R})$ \\
\hline 33 & ICGV 93260 & 1.99(R) & $3.40(\mathrm{R})$ & 4.73(R) & $5.38(\mathrm{MR})$ & $5.38(\mathrm{MR})$ \\
\hline 34 & ICGV 93261 & $2.47(\mathrm{R})$ & $6.83(\mathrm{MR})$ & $8.08(\mathrm{MR})$ & $8.70(\mathrm{MR})$ & $8.70(\mathrm{MR})$ \\
\hline 35 & ICGV 89280 & $3.18(\mathrm{R})$ & 7.03(MR) & 7.73(MR) & 7.73(MR) & 7.73(MR) \\
\hline 36 & ICGV 92195 & 2.92(R) & $6.51(\mathrm{MR})$ & 7.93(MR) & 8.67(MR) & 8.67(MR) \\
\hline 37 & ICGV 92035 & 3.74(R) & 7.58(MR) & 8.30(MR) & 9.12(MR) & 9.93(MR) \\
\hline 38 & ICGS 44 & $3.40(\mathrm{R})$ & $8.17(\mathrm{MR})$ & 8.89(MR) & 9.57(MR) & $10.21(\mathrm{MS})$ \\
\hline 39 & ICGS 76 & $3.00(\mathrm{R})$ & $4.42(\mathrm{R})$ & $4.42(\mathrm{R})$ & $5.12(\mathrm{MR})$ & $5.12(\mathrm{MR})$ \\
\hline 40 & ICR 48 & $0.03(\mathrm{HR})$ & $1.20(\mathrm{R})$ & $2.51(\mathrm{R})$ & $5.16(\mathrm{MR})$ & $6.47(\mathrm{MR})$ \\
\hline 41 & ICGV 86031 (Resistant check) & $1.34(\mathrm{R})$ & $4.04(\mathrm{R})$ & $4.04(\mathrm{R})$ & $4.04(\mathrm{R})$ & $4.04(\mathrm{R})$ \\
\hline \multirow[t]{2}{*}{42} & JL 24 (Susceptible check) & $4.88(\mathrm{R})$ & $10.88(\mathrm{MS})$ & $18.78(\mathrm{MS})$ & 20.96(MS) & $25.45(\mathrm{~S})$ \\
\hline & Mean of all genotypes & 2.51 & 5.41 & 6.94 & 7.51 & 7.81 \\
\hline
\end{tabular}

\begin{tabular}{|l|l|l|l|l|}
\hline \multicolumn{5}{|l|}{ Per cent disease incidence } \\
\hline Effect & Num DF & Den DF & F Value & Pr > F \\
\hline GEN & 41 & 77.5 & 2.63 & 0.0001 \\
\hline TIME & 4 & 338 & 94.74 & $<.0001$ \\
\hline GEN*TIME & 164 & 324 & 1.24 & 0.0513 \\
\hline
\end{tabular}

*Mean of three replications

SAS analysis was performed and the values mentioned are angular transformed values

R- Resistant; MR- Moderately Resistant; MS- Moderately Susceptible 
Table.2 Incidence of GBND in groundnut genotypes upon mechanical inoculation of groundnut bud necrosis virus at 1:10 dilution

\begin{tabular}{|c|c|c|c|c|}
\hline \multirow[b]{2}{*}{ S. No. } & \multirow[b]{2}{*}{ Genotype } & \multicolumn{3}{|c|}{ *GBND Incidence (\%) at } \\
\hline & & 7 DAI & 14 DAI & 21 DAI \\
\hline 1 & ICGV 99058 & $46.15(\mathrm{~S})$ & 92.31(HS) & 92.31(HS) \\
\hline 2 & ICGV 99072 & 73.33(HS) & 93.33(HS) & 93.33(HS) \\
\hline 3 & ICGV 00162 & $50.00(\mathrm{~S})$ & 94.44(HS) & 94.44(HS) \\
\hline 4 & ICGV 00187 & $22.22(\mathrm{MS})$ & $88.89(\mathrm{~S})$ & $100.00(\mathrm{~S})$ \\
\hline 5 & ICGV 00189 & $50.00(\mathrm{~S})$ & $100.00(\mathrm{HS})$ & $100.00(\mathrm{HS})$ \\
\hline 6 & ICGV 00191 & $38.89(\mathrm{~S})$ & 77.78(HS) & $83.33(\mathrm{HS})$ \\
\hline 7 & ICGV 00201 & $44.44(\mathrm{~S})$ & 83.33(HS) & 83.33(HS) \\
\hline 8 & ICGV 00202 & $42.86(\mathrm{~S})$ & $85.71(\mathrm{HS})$ & $85.71(\mathrm{HS})$ \\
\hline 9 & ICGV 00203 & $16.67(\mathrm{MS})$ & 77.78(HS) & $88.89(\mathrm{HS})$ \\
\hline 10 & ICGV 00206 & $46.15(\mathrm{~S})$ & 84.62(HS) & $84.62(\mathrm{HS})$ \\
\hline 11 & ICGV 00211 & 53.33(HS) & 73.33(HS) & $80.00(\mathrm{HS})$ \\
\hline 12 & ICGV 00213 & $0.00(\mathrm{HS})$ & 87.50(HS) & 93.75(HS) \\
\hline 13 & ICGV 00241 & $50.00(\mathrm{~S})$ & $81.25(\mathrm{HS})$ & $87.50(\mathrm{HS})$ \\
\hline 14 & ICGV 00246 & $62.50(\mathrm{HS})$ & $81.25(\mathrm{HS})$ & $81.25(\mathrm{HS})$ \\
\hline 15 & ICGV 00247 & $37.50(\mathrm{~S})$ & $100.00(\mathrm{HS})$ & $100.00(\mathrm{HS})$ \\
\hline 16 & ICGV 86590 & $100.00(\mathrm{HS})$ & $100.00(\mathrm{HS})$ & $100.00(\mathrm{HS})$ \\
\hline 17 & ICGV 86699 & 64.71(HS) & $64.71(\mathrm{HS})$ & 64.71(HS) \\
\hline 18 & ICGV 91114 & 72.22(HS) & $100.00(\mathrm{HS})$ & $100.00(\mathrm{HS})$ \\
\hline 19 & ICGV 00308 & $77.78(\mathrm{HS})$ & 94.44(HS) & 94.44(HS) \\
\hline 20 & ICGV 03042 & $38.46(\mathrm{~S})$ & 61.54(HS) & 76.92(HS) \\
\hline 21 & ICGV 03057 & $0.00(\mathrm{HR})$ & 66.67(HS) & 66.67(HS) \\
\hline 22 & ICGV 06100 & 9.09(MR) & 72.73(HS) & 72.73(HS) \\
\hline 23 & ICGV 07222 & $14.29(\mathrm{MS})$ & $28.57(\mathrm{~S})$ & $85.71(\mathrm{HS})$ \\
\hline 24 & ICGV 07220 & $0.00(\mathrm{HR})$ & 55.56(HS) & 66.67(HS) \\
\hline 25 & ICGV 05155 & $6.25(\mathrm{MR})$ & $81.25(\mathrm{HS})$ & $87.50(\mathrm{HS})$ \\
\hline 26 & ICGV 06146 & $0.00(\mathrm{HR})$ & 75.00(HS) & $75.00(\mathrm{HS})$ \\
\hline 27 & ICGV 02266 & $50.00(\mathrm{~S})$ & $50.00(\mathrm{~S})$ & $100.00(\mathrm{HS})$ \\
\hline 28 & ICGV 87846 & 25.00(MS) & $81.25(\mathrm{HS})$ & $87.50(\mathrm{HS})$ \\
\hline 29 & ICGV 93468 & $27.78(\mathrm{~S})$ & 94.44(HS) & 94.44(HS) \\
\hline 30 & ICGV 00348 & $33.33(\mathrm{~S})$ & 94.44(HS) & 94.44(HS) \\
\hline 31 & ICGV 00350 & 23.53(MS) & $100.00(\mathrm{HS})$ & $100.00(\mathrm{HS})$ \\
\hline 32 & ICGV 00351 & 20.00(MS) & 93.33(HS) & $100.00(\mathrm{HS})$ \\
\hline 33 & ICGV 93260 & 66.67(HS) & 66.67(HS) & 77.78(HS) \\
\hline 34 & ICGV 93261 & $66.67(\mathrm{HS})$ & 94.44(HS) & 94.44(HS) \\
\hline 35 & ICGV 89280 & 11.11(MR) & 94.44(HS) & 94.44(HS) \\
\hline 36 & ICGV 92195 & 16.67(MS) & 94.44(HS) & 94.44(HS) \\
\hline 37 & ICGV 92035 & 5.88(MR) & $100.00(\mathrm{HS})$ & $100.00(\mathrm{HS})$ \\
\hline 38 & ICGS 44 & 6.25(MR) & 93.75(HS) & 93.75(HS) \\
\hline 39 & ICGS 76 & $0.00(\mathrm{HR})$ & 92.31(HS) & 92.31(HS) \\
\hline 40 & ICR 48 & $0.00(\mathrm{HR})$ & $100.00(\mathrm{HS})$ & $100.00(\mathrm{HS})$ \\
\hline 41 & ICGV 86031 (Resistant check) & $33.33(\mathrm{~S})$ & 72.22(HS) & 72.22(HS) \\
\hline 42 & JL 24 (Susceptible check) & $44.44(\mathrm{~S})$ & 94.44(HS) & 94.44(HS) \\
\hline & Mean of all genotypes & 34.46 & 83.77 & 88.79 \\
\hline
\end{tabular}

*Mean of three replications

SAS analysis was performed and the values mentioned are angular transformed values

HR - Highly resistant; R- Resistant; MR- Moderately Resistant; S - Susceptible; MS- Moderately Susceptible; HS Highly Susceptible

DAI - Days After Inoculation 
Table.3 Incidence of GBND in groundnut genotypes upon mechanical inoculation of groundnut bud necrosis virus at 1:100dilution

\begin{tabular}{|c|c|c|c|c|}
\hline \multirow[b]{2}{*}{ S. No. } & \multirow[b]{2}{*}{ Genotype } & \multicolumn{3}{|c|}{ *GBND Incidence (\%) at } \\
\hline & & 7 DAI & 14 DAI & 21 DAI \\
\hline 1 & \begin{tabular}{|l|} 
ICGV 99058 \\
\end{tabular} & $50.00(\mathrm{~S})$ & 58.33(HS) & $58.33(\mathrm{HS})$ \\
\hline 2 & ICGV 99072 & 78.57(HS) & 85.71(HS) & 85.71(HS) \\
\hline 3 & ICGV 00162 & $60.00(\mathrm{HS})$ & $60.00(\mathrm{HS})$ & 73.33(HS) \\
\hline 4 & ICGV 00187 & $22.22(\mathrm{MS})$ & $27.78(\mathrm{~S})$ & $44.44(\mathrm{~S})$ \\
\hline 5 & ICGV 00189 & 52.94(HS) & 52.94(HS) & 52.94(HS) \\
\hline 6 & ICGV 00191 & $38.89(\mathrm{~S})$ & $38.89(\mathrm{~S})$ & $38.89(\mathrm{~S})$ \\
\hline 7 & ICGV 00201 & $47.06(\mathrm{~S})$ & $47.06(\mathrm{~S})$ & 52.94(HS) \\
\hline 8 & ICGV 00202 & $33.33(\mathrm{~S})$ & $33.33(\mathrm{~S})$ & $33.33(\mathrm{~S})$ \\
\hline 9 & ICGV 00203 & $18.75(\mathrm{MS})$ & $25.00(\mathrm{MS})$ & $37.50(\mathrm{~S})$ \\
\hline 10 & ICGV 00206 & $35.29(\mathrm{~S})$ & 58.82(HS) & 58.82(HS) \\
\hline 11 & ICGV 00211 & $47.06(\mathrm{~S})$ & 52.94(HS) & 52.94(HS) \\
\hline 12 & ICGV 00213 & $0.00(\mathrm{HR})$ & 5.56(MR) & $5.56(\mathrm{MR})$ \\
\hline 13 & ICGV 00241 & 57.14(HS) & 64.29(HS) & 64.29(HS) \\
\hline 14 & ICGV 00246 & $55.56(\mathrm{HS})$ & 72.22(HS) & 77.78(HS) \\
\hline 15 & ICGV 00247 & $40.00(\mathrm{~S})$ & $46.67(\mathrm{~S})$ & 53.33(HS) \\
\hline 16 & ICGV 86590 & $100.00(\mathrm{HS})$ & $100.00(\mathrm{HS})$ & $100.00(\mathrm{HS})$ \\
\hline 17 & \begin{tabular}{|l|} 
ICGV 86699 \\
\end{tabular} & 70.59(HS) & $88.24(\mathrm{HS})$ & $88.24(\mathrm{HS})$ \\
\hline 18 & ICGV 91114 & $72.22(\mathrm{HS})$ & $72.22(\mathrm{HS})$ & $72.22(\mathrm{HS})$ \\
\hline 19 & \begin{tabular}{|l|} 
ICGV 00308 \\
\end{tabular} & $82.35(\mathrm{HS})$ & $82.35(\mathrm{HS})$ & $82.35(\mathrm{HS})$ \\
\hline 20 & ICGV 03042 & $50.00(\mathrm{~S})$ & $50.00(\mathrm{~S})$ & $50.00(\mathrm{~S})$ \\
\hline 21 & ICGV 03057 & $0.00(\mathrm{HR})$ & $0.00(\mathrm{HR})$ & $11.11(\mathrm{MR})$ \\
\hline 22 & ICGV 06100 & 9.09(MR) & $27.27(\mathrm{~S})$ & $36.36(\mathrm{~S})$ \\
\hline 23 & ICGV 07222 & $8.33(\mathrm{MR})$ & $25.00(\mathrm{MS})$ & $25.00(\mathrm{MS})$ \\
\hline 24 & ICGV 07220 & $0.00(\mathrm{HR})$ & 11.11(MS) & $22.22(\mathrm{MS})$ \\
\hline 25 & ICGV 05155 & $6.25(\mathrm{MR})$ & $25.00(\mathrm{MS})$ & $37.50(\mathrm{~S})$ \\
\hline 26 & ICGV 06146 & $0.00(\mathrm{HR})$ & $0.00(\mathrm{HR})$ & $7.14(\mathrm{MR})$ \\
\hline 27 & ICGV 02266 & $50.00(\mathrm{~S})$ & $50.00(\mathrm{~S})$ & $100.00(\mathrm{HS})$ \\
\hline 28 & ICGV 87846 & $25.00(\mathrm{MS})$ & $56.25(\mathrm{HS})$ & $56.25(\mathrm{HS})$ \\
\hline 29 & ICGV 93468 & $27.78(\mathrm{~S})$ & $55.56(\mathrm{HS})$ & $66.67(\mathrm{HS})$ \\
\hline 30 & ICGV 00348 & $33.33(\mathrm{~S})$ & $55.56(\mathrm{HS})$ & $55.56(\mathrm{HS})$ \\
\hline 31 & ICGV 00350 & $22.22(\mathrm{MS})$ & 61.11(HS) & $77.78(\mathrm{HS})$ \\
\hline 32 & ICGV 00351 & $16.67(\mathrm{MS})$ & 61.11(HS) & $61.11(\mathrm{HS})$ \\
\hline 33 & ICGV 93260 & $44.44(\mathrm{~S})$ & $44.44(\mathrm{~S})$ & $50.00(\mathrm{~S})$ \\
\hline 34 & ICGV 93261 & 66.67(HS) & $72.22(\mathrm{HS})$ & $72.22(\mathrm{HS})$ \\
\hline 35 & ICGV 89280 & $11.11(\mathrm{MS})$ & $55.56(\mathrm{HS})$ & $72.22(\mathrm{HS})$ \\
\hline 36 & ICGV 92195 & 16.67(MS) & 61.11(HS) & 61.11(HS) \\
\hline 37 & ICGV 92035 & $5.56(\mathrm{MR})$ & 72.22(HS) & $72.22(\mathrm{HS})$ \\
\hline 38 & ICGS 44 & 6.67(MR) & $46.67(\mathrm{~S})$ & $46.67(\mathrm{~S})$ \\
\hline 39 & ICGS 76 & $0.00(\mathrm{HR})$ & $25.00(\mathrm{MS})$ & $25.00(\mathrm{MS})$ \\
\hline 40 & ICR 48 & $0.00(\mathrm{HR})$ & $25.00(\mathrm{MS})$ & $33.33(\mathrm{~S})$ \\
\hline 41 & ICGV 86031 (Resistant check) & $6.67(\mathrm{MR})$ & 13.33(MS) & $26.67(\mathrm{~S})$ \\
\hline \multirow[t]{2}{*}{42} & JL 24 (Susceptible check) & 66.67(HS) & 77.78(HS) & 77.78(HS) \\
\hline & Mean of all genotypes & 34.17 & 48.66 & 54.21 \\
\hline
\end{tabular}

*Mean of three replications

SAS analysis was performed and the values mentioned are angular transformed values

HR - Highly resistant; R- Resistant; MR- Moderately Resistant; S - Susceptible; MS- Moderately Susceptible; HS -

Highly Susceptible

DAI - Days After Inoculation 
Fig.1 Disease severity of certain groundnut advanced breeding lines for their reaction to Groundnut bud necrosis disease (GBND) under greenhouse and field conditions

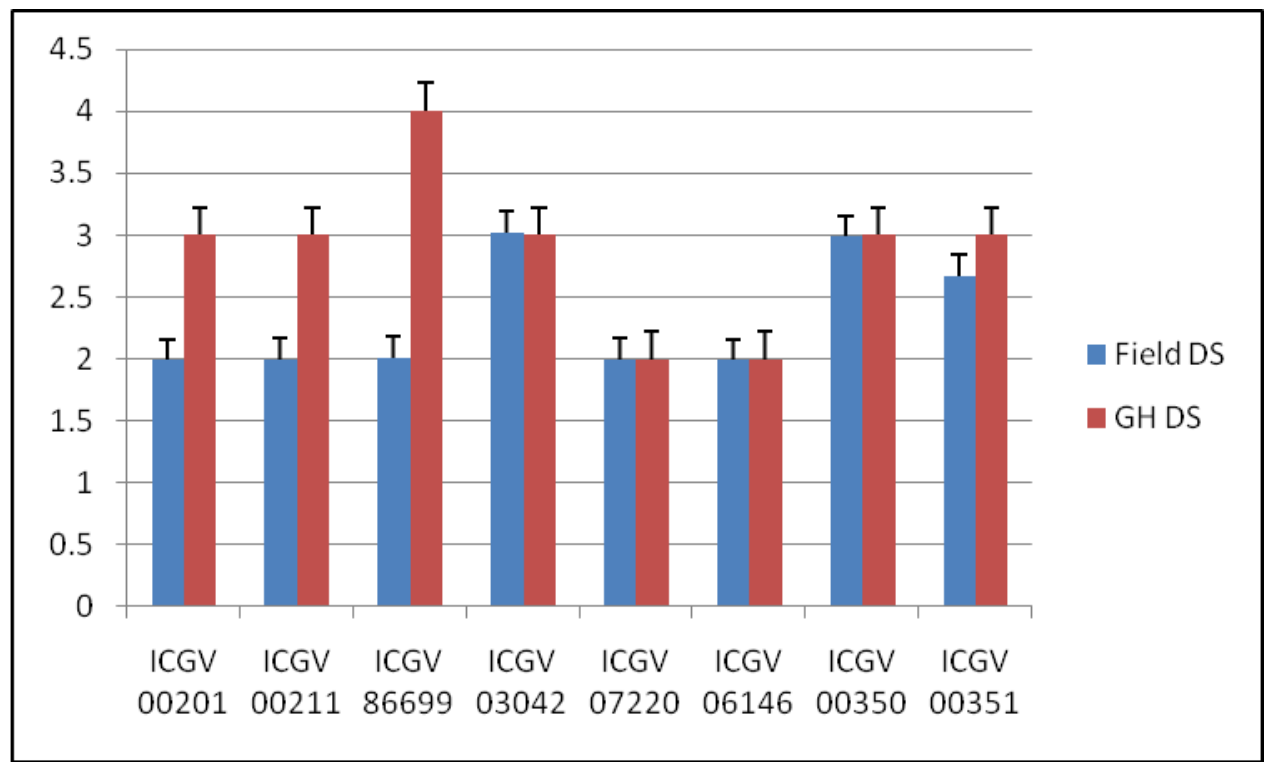

The above results indicate longer incubation period of virus inside the host plant which may be due to unsuitable environment in the host plant or may be due to block in movement of virus inside the plant due to host defense response. Young tissue and young plants are more susceptible while mature tissue and plants are highly resistant to GBNV (Buiel and Parlevliet, 1996). Disease incidence decreased and incubation period increased with the age of plants and leaves. This type of resistance (mature plant and tissue) occurs irrespective of the susceptibility level of the genotype to GBNV. However, this type of resistance develops earlier in the resistant than in the susceptible genotype.

In the present study, none of the groundnut genotypes screened under artificial inoculated conditions using sap of the virus were highly resistant or resistant to the GBND. This could be attributed to the high inoculum pressure of the virus. However, the reaction of these genotypes may change, if the screening is attempted with lower virus concentration of 1:100 or 1:1000 (Rao et al., 2003; Kalyani et al., 2005).
The resistant and susceptible genotypes could not be clearly differentiated by using disease severity scoring alone. This was even comparable with earlier results of some of the researchers (Pensuk et al., 2002; Buiel and Parlevliet, 1996) who reported the disadvantage of using disease severity scoring due to the highly variable symptoms caused by GBNV that are not primarily genotype specific. Disease incidence is more advantageous than disease score because it is easy to evaluate (Kesmala et al., 2006). Moreover, field evaluation of lines is complicated initially by the non-uniformity of disease distribution in the field resulting from random distribution of vectors.

At 1:10 virus concentration, the highly susceptible group of genotypes has 2-5 disease severity rating. While, at 1:100 virus concentrations, the moderately resistant and moderately susceptible group of genotypes had 2 severity rating, the susceptible and highly susceptible reaction group has 2-4 as their severity rating. This clearly shows the drawback in using disease severity as a parameter to measure the disease. 
The percent infection to GBNV antiserum and the absorbance values at $405 \mathrm{~nm}$ clearly differentiated the resistant and susceptible check at 1:10 and 1:100 virus concentrations. The ICGV 86031 (resistant check) showed 93.33 percent susceptibility when inoculated with 1:10 dilution of virus concentration and positive reaction with ELISA. This might be due to the high amount of virus applied. In support of our results, a previous study also reported that genotypes ICGV 86031 and ICGV 86388 succumbed to GBND under high disease pressure and recorded substantial yield losses (Reddy et al., 2000).

The genotype ICGV 06146 showed resistant reaction in field and moderately resistant reaction in greenhouse screening. ICGV 00213 showed moderately resistant reaction in both field and greenhouse screening. The genotypes viz., ICGV 07222, 03057 and ICGS 76 showed moderately resistant reaction in field and moderately susceptible reaction in greenhouse. ICGV 00187, 00191, 00202, 00203, 06100, 93260, 05155 and ICR 48 gave moderately resistant reaction in field and susceptible reaction in greenhouse. ICGV 03042 showed resistant reaction in field and susceptible reaction in greenhouse. ICGV 07220 showed resistant reaction in field and moderately susceptible reaction in greenhouse. ICGS 76 showed moderately resistant reaction in field and moderately susceptible reaction in greenhouse (Figure 1).

The genotypic differences may be due to inherent response for resistance and susceptibility to GBNV. The genotypes mentioned above that showed variable degree of resistance under field and greenhouse conditions had Spanish bunch growth habit except ICGS 76 and ICR 48 which had Virginia bunch growth habit.

The genotypes viz., ICGV 00187, 00191, 00202, 00203, 00213, 06146 and ICGV
93260 were also reported as resistant for foliar diseases whereas, the genotypes viz., ICGV 03057, 07222, 07220, 05155 and ICR 48 were drought resistant.

The resistant check (ICGV 86031) used in the study showed resistant reaction in field and susceptible reaction in greenhouse. And the susceptible check (JL 24) showed susceptible reaction in field and highly susceptible reaction in greenhouse. This implies that most probably ICGV 86031 is resistant to vector $T$. palmi and susceptible to GBNV whereas, JL 24 is susceptible to both vector and virus. In our study, the resistance showed by test genotypes could be associated with nonpreference of the vector or slower multiplication of virus in the host plant. In any case both the characters are of good value for a resistant genotype. Further screening of these advanced breeding lines in multilocation trails will help in direct release of these genotypes as promising varieties in hot spot locations of the country where GBND is prevalent.

\section{Acknowledgements}

We sincerely thank Dr. P. Janila, Groundnut Breeder at ICRISAT for providing the seed of groundnut advanced breeding lines. This work was supported by the CGIAR Research Program on Grain Legumes.

\section{References}

Adams, M.J., Lefkowitz, E. J., King, A.M. Q., Harrach, B., Harrison, R.L., Knowles, N. J., Kropinski, A.M., Krupovic, M., Kuhn, J.H., Mushegian, A.R., Nibert, M., Sabanadzovic, S., Sanfacon, H., Siddell, S.G., Simmonds, P., Varsani, A., Zerbini, F.M., Gorbalenya, A. E., Davison, A. J. 2017. Changes to taxonomy and the International code of virus classification and nomenclature ratified by the International Committee on Taxonomy of 
Viruses.Arch Virol.162 (8): 2463-2466.

American Phytopathological Society (APS). Peanut Bud Necrosis Disease. 23 April 2013.

Amin, P.W., 1985. Apparent resistance of groundnut cultivar Robut 33-1 to bud necrosis disease. Plant Dis. 69: 718-719.

Basu, M.S., 1995. Peanut bud necrosis disease: activities in the Indian National Programme. In recent Studies on PBND: Proceedings of a meeting, 20 March 1995. ICRISAT Asia center. India. 61-63.

Briese, T., Alkhovsky, S., Beer, M., Calisher, C. H., Charrel, R., Ebihara, H., Jain. R., Kuhn, J. H., Lambert, A., Maes, P., Nunes, M., Plyusnin, A., Schmaljohn, C., Tesh, R.B., Yeh, S-D, Elbeaino, T., Digiaro, M., Martelli, G.P., Muehlbach, H-P., MielkeEhret, N., Sasaya, T., Choi, I.R., Haenni, AL., Jonson, G., Shirako, Y., Wei, T., Zhou, X., Junglen, S. 2017. ICTV taxonomic proposal 2016.030a-vM.A.v6.Bunyavirales. Create the order Bunyavirales, including eight new families, and one renamed family. http://www.ictv.global/proposals16/2016.030a-vM.A.v6.Bunyavirales.pdf. Accessed on 27 April 2017.

Buiel, A.A.M., and Parlevliet, J.E. 1996. Mature plant and tissue resistance in the groundnutpeanut bud necrosis virus system. Euphytica. 91(2): 213-217.

Culbreath, A.K., Todd, J.W., and Brown, S.L. 2003. Epidemiology and management of tomato spotted wilt in peanut. Annu. Rev. Phytopathol. 41: 53-75.

Culbreath, A.K., Todd, J.W., Gorbet, D.W., and Demski, J.W. 1993. Spotted wilt apparent disease progress in the component lines of Southern Runner cultivar. Peanut Science. 20: 81-84.

Dwivedi, S.L., Nigam, S.N., Reddy, D.V.R., Reddy, A.S., and Ranga Rao, G.V. 1995. Progress in breeding groundnut varieties resistant to Peanut bud necrosis virus and its vector. Recent studies on peanut bud necrosis disease: proceedings of a meeting, 20 March, 1995. International Crops Research Institute for Semi-Arid Tropics, Patancheru, India. 35-40.

Food and Agriculture Organization of the United Nations. FAOSTAT. 07 February 2014. http://faostat.fao.org/site/567/default.aspx\#a ncor.

Hobbs, H.A., Reddy, D.V. R., Rajeswari, R., and Reddy, A.S. 1987. Use of direct antigen coating and protein A coating ELISA procedures for detection of three peanut viruses. Plant Dis. 71: 747-749.

Kalyani, G., Sonali, S., Reddy, A.S., Reddy, A.G.S., Waliyar, F., and Nigam, S.N. 2005. Resistance to Tobacco streak virus in groundnut, Arachis hypogaea. J. Oilseeds Res. 22: 105-107.

Kesmala, T., Jogloy, S., Wongkaew, S., Akkasaeng, C., and Patanothai, A. 2006. Evaluation of ten peanut genotypes for resistance to Peanut bud necrosis virus (PBNV). Songklanakarin J. Sci. Technol. 28(3): 459-467.

Mumford, R.A., Barker, I., and Wood, K.R. 1996. The biology of the tospoviruses. Ann. Appl. Biol. 128: 159-183.

Nwokolo, E., 1996. Food and feed from legumes and oilseeds. Peanut (Arachis hypogaea L.). Chapman and Hall Publishing Co. Pvt. Ltd. New York. 49-63.

Pappu, H.R., 1997. Managing tospoviruses through biotechnology: progress and prospects. Biotechn. and Develop. Monitor. 32: 14-17.

Pearce, M., 2005. 2004 Georgia Plant Disease Loss Estimates. University of Georgia cooperative extension services. Georgia. 24.

Pensuk, V., Daengpluang, N., Wongkaew, S., Jogloy, S., and Patanothai, A. 2002. Evaluation of screening procedures to identify peanut resistance to Peanut bud necrosis virus (PBNV). Peanut Science. 29(1): 47-51.

Persley, D.M., Thomas, J.E., and Sharman, M. 2006. Tospoviruses - an Australian perspective. Austral.Plan.Pathol. 35:161180.

Rao, C.S., Bhatnagar, M.P., Kumar, L.P., Reddy, A.S., and Sharma, K.K. 2013. Pathogenderived resistance using a viral nucleocapsid gene confers only partial nondurable protection in peanut against Peanut bud necrosis virus. Arch. Virol. 158: 133143.

Rao, C.S., Kumar, L.P., Reddy, A.S., Krishna, S.T., Waliyar, F., Nigam, S., Laxminarasu, 
M., and Sharma, K.K. 2006. Development and evaluation of transgenic peanut plants against peanut bud necrosis disease (PBND) under greenhouse and field conditions. Indian J. Virol. 17(2): 135-136.

Rao, R.D.V.J.P., Reddy, D.V.R., Nigam, S.N., Reddy, A.S., Waliyar, F., Yellamanda Reddy, T., Subramanyam, K., John Sudheer, M., Naik, K.S.S., Bandopadhyay, A., Desai, S., Ghewande, M.P., Basu, M.S., and Somasekhar. 2003. Peanut Stem Necrosis: A New Disease of Groundnut in India. Information Bulletin no. 67. Patancheru 502 324, Andhra Pradesh, India: International Crops Research Institute for the Semi-Arid Tropics. 16.

Reddy, A.S., Reddy, L.J., Mallikarjuna, N., Abdurahaman, M. D., Reddy, Y.V., Bramel, P.J., and Reddy, D.V.R. 2000. Identification of resistance sources to Peanut bud necrosis virus (PBNV) in wild Arachis germplasm. Ann. Appl. Biol. 137: 135-139.

Reddy, D. V. R., 1991. Groundnut viruses and virus diseases: distribution, identification and control. Annu. Rev. Plant Path. 70: 665-680.

Reddy, D.V.R., Buiel, A.A.M., Satyanarayana, T., Dwivedi, S.L., Reddy, A.S., Ratna, A.S., Vijayalakshmi, K., Rao, G.V.R., Naidu, R.A., and Wightman, J.A. 1995. Peanut bud necrosis disease: an overview. In recent studies on peanut bud necrosis disease: Proceedings of a meeting, 20 March 1995, International Crops Research Institute for Semi-Arid Tropics, Patancheru, India. 3-7

Reddy, D.V.R., Ratna, A.S., Sudarshana, F.P., and Kumar, K.I. 1992. Serological relationships and purification of bud necrosis virus, a tospovirus occurring in peanut (Arachis hypogaea L.) in India. Ann. Appl. Biol. 120: 279-286.

Sreekanth, M., Sreeramulu, M., Rao, R.D.V.J.P., Babu, B.S., and Babu, T.R. 2002. Effect of sowing date on Thripspalmi Karny population and peanut bud necrosis virus incidence in greengram (Vigna radiata $\mathrm{L}$. Wilczek). Indian J. Plant Prot. 30(1): 16-21.

Sunkad, G., Kenchanagoudar, P.V., and Naragund, V.B. 2000. Identification of sources for field resistance to Peanut bud necrosis disease in groundnut. Karnataka J. Agric. Sci. 15(4): 646-648.

Vijayalakshmi, K., 1995. Transmission and ecology of Thripspalmi Karny the vector of Peanut bud necrosis virus. Ph.D. Thesis. Andhra Pradesh Agricultural University, Hyderabad, India. 1-98.

Wongkaew, S., 1995. Peanut bud necrosis disease in Thailand. In recent Studies on PBND: Proceedings of a meeting, 20 March 1995. ICRISAT Asia center. India. 55-59.

\section{How to cite this article:}

Afsha Tabassum, Bharati N. Bhat and Sudini, H. 2017. Reaction of Groundnut Advanced Breeding Lines to Groundnut Bud Necrosis Disease. Int.J.Curr.Microbiol.App.Sci. 6(10): 1790-1802. doi: https://doi.org/10.20546/ijcmas.2017.610.216 